УДК 32:(30+330.837)

https://doi.org/10.34142/24130060.2020.20.1.01

\title{
СУЧАСНІ ПОЛІТИЧНІ ДОСЛІДЖЕННЯ У КОНТЕКСТІ НЕОІНСТИТУЦІОНАЛІЗМУ: СТРАТЕГІЇ НАУКОВИХ РОЗВІДОК
}

\author{
С. А. Бабухіна, Т. П. Савельсва
}

Харківський національний педагогічний університет імені Г.С. Сковороди

Стаття містить спробу визначення стратегій наукових розвідок в сучасних політичних дослідженнях в контексті визначення пізнавальних можливостей неоінституиіонального підходу.

Визначається, щуо даний напрямок є логічним розвитком інституціоналізму, у зв'язку із чим надаються загальні характеристики «нового» підходу у порівнянні зі «старим». Особлива увага звертається на такі характеристики як: категоріальнопонятійний апарат дослідження, його основні принципи, рівні, особливості предметного поля, методи.

Ключові слова: інституціоналізм, неоінституцฺіоналізм, інститути, політичні інститути.

\section{СОВРЕМЕННЫЕ ПОЛИТИЧЕСКИЕ ИССЛЕДОВАНИЯ В КОНТЕКСТЕ НЕОИНСТИТУЦИОНАЛИЗМА: СТРАТЕГИИ НАУЧНЫХ ПОИСКОВ}

\author{
С. А. Бабухина, Т. П. Савельева
}

В статье содержится попытка определения стратегий научных поисков в современных политических исследованиях в контексте определения познавательных возможностей неоинституционального подхода.

Определяется, что данное направление является логическим развитием институционализма, в связи, с чем представляются общие характеристики «нового» подхода по сравнению со «старым». Особое внимание обращается на такие характеристики как: категориально-понятийный аппарат исследования, его основные принциипы, уровни, особенности предметного поля, методы.

Ключевые слова: институционализм, неоинституционализм, институты, политические институть.

\section{CONTEMPORARY POLITICAL ISSUES IN THE CONTEXT OF NEOINSTITUTIONALISM: STRATEGIES OF SCIENCE RESEARCH}

\section{S. Babuhina, T. Savelieva}

The article contains an attempt to determine the strategies of scientific research in contemporary political issues in the context of determining the cognitive capabilities of the neoinstitutional approach. 
It has been determined that neoinstitutionalism is a logical development of the "old" institutionalism, its addition with new ideas to increase cognitive capabilities, a new rethinking of modern processes of political life.

Attention is drawn to the fact that neoinstitutionalism is a rather heterogeneous line, but at the same time it is made an attempt to highlight the common features of the new approach in all its variants. It is made a comparison between the "old" and "new" institutionalism to do this, which is based on: categorical-conceptual apparatus, principles, levels of research, methods.

The author identifies the key postulates of neoinstitutionalism, they emphasize the importance of institutions. And it is emphasized that the subject field of this approach is expanding due to the fact that the attention of researchers is directed not so much to the institutions themselves, but to the activities of political actors.

Among the features of research within the framework of this approach, the following are also distinguished: rejection of descriptiveness, attempts to build a sufficiently structured theory through the use of the deduction method; focusing on the study of the results of public policy in the form of political decisions, government programs, strategies, etc.; adherence to the principle of methodological individualism; use of quantitative analysis methods; use of multilevel analysis.

The cognitive capabilities of this theory in modern political studies are determined, based on a detailed analysis of the key features of the neoinstitutional approach; it is also proposed to highlight possible elements of the research scheme of this approach, which will help to more rationally use the possibilities of the new institutional theory: , the definition of the levels of analysis, or the conduct of the research in an integrated manner, within all levels: institutional, organizational, individual, depending on the purpose of the research; consideration of research objects as institutionalized practices, formal / informal rules of the game; analysis of the institutional environment; analysis of sociocultural contexts; analysis of dynamics, policy results.

Key words: institutionalism, neoinstitutionalism, institutions, political institutions.

Постановка проблеми. Сучасність, спостерігачами якої ми $є$ вже декілька десятиліть, характеризується нестабільністю, мінливістю, непередбачуваністю, що вимагає наукового пошуку найбільш доцільних та відповідних сучасним умовам теоретико-методологічних підходів для дослідження явищ та процесів, що «випадають» із звичних стандартів або ж не «закріплені» в межах політичної науки (нові суспільні рухи, корупція, саботаж, тощо).

Якщо у традиційному вимірі політичної науки звертається увага на інституціоналізовані практики як ядро політичного процесу, то у сучасних умовах, які з точки зору провідних науковців постають як нетрадиційні периферійні неформальні практики політичного процесу переміщуються до його центру.

Осягнення нестандартних явищ, неформальних практик вимагає застосування теорій, що мали б змогу адекватно пояснити соціально- 
політичну картину сучасного світу. Серед таких теорій, які можна назвати некласичними за рахунок нестандартних для політичної науки кінця XX ст. положень, слідом за низкою західних вчених, можна визнати неоінституціоналізм, який у якості стратегії дослідження потребує визначення специфіки та дослідницької схеми, яка може бути застосована для аналізу сучасних соціально-політичних явищ та політичних процесів в українському суспільстві. Дана стратегія актуалізується при дослідженні ключових тем сьогодення - гібридні (інформаційні) війни, сучасна армія, корупція, нові суспільні рухи, саботаж тощо.

Аналіз актуальних досліджень. Розвиток неоінституціонального підходу в політичній науці представлений великою кількістю наукових розвідок західних вчених, серед яких П. ДіМаджіо, Дж. Марч, Дж. Мейєр, Д. Норт, Й. Олсон, У. Пауелл, Б. Роуен, Т. Скочпол та інші. Вітчизняні вчені останне десятиліття також приділяють увагу неоінституціоналізму у якості однієї зі стратегій політичних досліджень: І. Денисенко та Ю. Тяпкіна (дослідження армії), І. Кушнарьов (корупція), А. Романюк (використання у порівняльній політології), М. Чабанна (процес прийняття політичних рішень), та інші. В той же час, в політологічних розвідках вчених мало уваги приділяється розгляду загальної дослідницької схеми неоінституціоналізму, можливо, у першу чергу, через «багатоманітність» його варіантів (так званих неоінституціоналізмів).

Отже, метою статті $\epsilon$ спроба визначення можливостей неоінституціонального підходу у якості однісї зі стратегій дослідження в сучасних політологічних розвідках як традиційних для політичної науки явищ i процесів, так і нетрадиційних, через окреслення тих ключових елементів, що можуть бути використані для побудови дослідницької схеми даного підходу в межах політичної науки.

Виклад основного матеріалу. На думку авторитетних науковців неоінституціоналізм сьогодні $\epsilon$ домінуючим в політичній науці та знаходиться серед підходів, які набули досить великої популярності і 
показали свою динамічність у розвитку відповідно до оновленої картини світу. 3 одного боку, дана теорія має традиціоналістську основу, адже базою для неї є інституціоналізм (так званий «старий» інституціоналізм був однією iз основних теорії у дослідженні політики), з іншого - вона є доцільною для аналізу сучасних політичних процесів та явищ.

Виникнення неоінституціоналізму датується 80-ми роками $\mathrm{XX}$ століття. Неоінституціоналізм набув активного розвитку за умов розвитку демократії та поширення досить незвичних для такого режиму явищ сепаратизму, релігійного фундаменталізму, тероризму, політичного екстремізму (Apter, 1999, s. 374).

На думку К. фон Байме (2005, s. 90) розвиток нового інституціоналізму проходить в першу чергу в межах теорії модернізації, яка наголошувала на одному 3 головних чинників суспільних змін - розвитку політичних інститутів. Існує навіть думка, що неоінституціоналізм являє собою поєднання так званого «старого» інституціоналізму із теоріями розвитку (Apter, s. 374), та розглядається як відроджений інституціоналізм, реакція на пануючий у той час біхевіоралізм (у Ф. Кирилюка (2009, s. 411) даний напрямок характеризується як «необіхевіористське осмислення сучасних процесів політичного життя».

Отже, можна сказати, що теорія нового інституціоналізму постає в політичній думці не як протиставлення інституціоналізму («старому»), а як його розвиток, доповнення новими ідеями задля підвищення пізнавальних можливостей, що пов'язано із суспільно-політичним розвитком, новими реаліями, масштабними політичними перетвореннями ХХ століття та загалом із розвитком політичної теорії.

Причини появи оновленої теорії пов’язують із необхідністю адекватної репрезентації політичної реальності у теорії; із визнанням вирішальної ролі інститутів у якості посередників для формування політичної поведінки; із визнанням складності та непередбачуваності політичних систем (Zaznaev, 2005, s. 14). 
Необхідно звернути увагу, що неоінституціоналізм $є$ досить неоднорідною течію, при чому як у методологічному, так і у ідейному плані (Kokarev, 2009, s. 40). Але, як зазначає С. Патрушев (2001, s. 160), усі відгалуження у даній теорії, усі іiі варіанти ніяким чином не суперечать один одному, а, навпаки, взаємодоповнюють один одного.

Наводячи класифікацію даної теорії, С. Патрушев (2001, s. 160-61) виокремлює в ній вісім підходів. Саме в межах політичної науки сформувалося два різновиди - історичний інституціоналізм (виник в порівняльній політології) та інституціоналізм раціонального вибору (в основі американська політика та міжнародні відносини) (Fligstin, 2001, s. 40). Серед найбільш актуальних саме для політичної науки українські вчені пропонують виокремити наступні: соціологічний (в тому числі одна 3 його форм нормативний), історичний, неоінституціоналізм обмеженого раціонального вибору (Kolodii, 2011 s. 132).

Така різнорідність та багатогранність нового інституціоналізму пояснюється відмінностями у концептуалізації інституційного контексту, особливостями його походження (синхронне, діахронічне, індивідуальне, колективне, тощо) та його використанням тими чи іншими науками (економіка, політологія, соціологія, психологія, філософія) (Patrushev, 2009, s. 7).

«Різноманіття інституціоналізмів» не виключає наявності загальних рис у даному теоретичному напрямі, які і можуть слугувати відправною точкою для розробки як загальної дослідницької схеми в межах даного підходу, так і виокремлення іiі окремих елементів, що може слугувати основою для обгрунтування використання даного підходу в сучасних наукових розвідках.

Пропонуємо звернути увагу на зміни, що відбуваються в новому підході (неоінституціоналізмі) у порівнянні зі «старим» інституціоналізмом це зміни, що стосуються категоріально-понятійного апарату дослідження, 
його принципів, рівнів, предметного поля, методів та процедури аналізу (Denysenko ta Tiapkina, 2019, s. 80).

Досить узагальнену, але ключову характеристику неоінституціональному підходу надав К. фон Байме (2008, s. 128), порівнявши його із інституціоналізмом. Інституціональний підхід науковець характеризує як такий, що «обтяжений присмаком консервативності», дещо спрощений та механістичний щодо розгляду системи, в свою чергу, неоінституціоналізм, на його думку, оперує більш новими підходами, до того ж, його головна відмінність від інституціоналізму - не все пояснюється через інституції (передбачається, що завжди існують ситуації, де виникають «мало закріплені політичні процеси») (Baime, 2008, s. 135).

Слід зауважити, що для обох інституціоналізмів - i «старого» i «нового», ключове положення формулюється загальновживаним виразом «інституції мають значення» (окреслюється важливість існування та аналізу інститутів), або ж «інституції формують політику та історію».

Серед ключових постулатів нового напрямку визначають наступні:

- політичні інститути постають повноправними акторами політики через наявність власних інтересів;

- інститути впливають на поведінку людини через встановлення певних обмежень за допомогою правил;

- інститути визначають результати політики та постають їі основними детермінантами у визначенні результатів політики через усвідомлення політичними акторами своїх цілей (Mer, 1999, s. 313-314).

За словами Б. Пітерса (1999, s. 218), даний підхід вивчає «скоріш реальну поведінку, ніж лише формальні, структурні аспекти інститутів». Отож, увага дослідників акцентована не стільки на самі інститути, а на діяльність політичних акторів, що спрямована на їх підтримку чи зміни. В даному положенні можна побачити, що, в тому числі за рахунок «біхевіористських акцентів», неоінституціоналізм характеризується більш широким предметним полем дослідження. 
Серед особливостей дослідження в межах даного підходу можна також визначити наступні: відмова від описовості, намагання побудови досить структурованої теорії за рахунок використання методу дедукції; спрямування уваги на вивчення результатів публічної політики у вигляді політичних рішень, державних програм, стратегії тощо (на відміну від дослідження організації чи процесів усередині політичних структур) (Patrushev, 2001, s. 155); дотримання принципу методологічного індивідуалізму (визнання реальними акторами соціально-політичного процесу не груп та організацій а діючих індивідів); використання методів кількісного аналізу; досить широкий тематичний спектр неоінституційного аналізу передбачає використання декілька рівнів дослідження - інституційний/макрорівень (розглядаються загальні закономірності розвитку, особливості інституційного середовища, особливості відтворення соціально-політичних інститутів), організаційний/мезорівень (безпосередньо створення тих чи інших організаційних форм в залежності від інституційного середовища), індивідуальний/макрорівень (особливості інституційної практики, дії індивідуальних акторів) (Patrushev, 2001, s. 153).

Якщо говорити про смислове наповнення ключових категорій, необхідно зазначити, що, по-перше, в межах неоінституціоналізму 3'являються нові поняття, найчастіше запозичені із різних галузей знань, теорій, як, наприклад, «трансакційні видатки», «опортуністична поведінка», «поля», «арени», «ігри», «інституційна практика» тощо; по-друге, ключовим поняттям даної теорії залишається «інститут»/«політичний інститут», яке в межах неоінституціоналізму набуває свого особливого сенсу та постає у якості визначального вектору політичного розвитку, що забезпечує стабільність, усталеність зразків поведінки, передбачуваність (Vaslavskij i Gabuev, 2016, s. 64); та, по-третє, новий зміст отримують традиційні поняття політичної науки.

Вважається, що поняття інститутів, характерне практично для усіх напрямків неоінституціоналізму, визначено у праці Дж. Марча та Й. Олсена 
«Новий інституціоналізм: організаційні фактори у політичному житті», де автори розглядають інститути як «відносно стійкий набір правил та організованих практик, втілений у структурах значень та ресурсів, які $є$ інваріантними по відношенню до індивідів і стійкими перед специфічними вподобаннями та очікуваннями індивідів а також перед зовнішніми умовами, які схильні до мінливості» (Rhodes and Burder, p. 3). Але дане визначення не окреслює усієї глибинної сутності «неоінституційного розуміння» інститутів. Аналіз ключових публікацій 3 неоінституційної тематики дозволяє виокремити наступні характеристики інститутів, притаманні даній теорії.

На відміну від інституційного підходу із характерною особливістю щодо розгляду інститутів у якості культурних та психологічних явищ (політичний інститут інтерпретувався як нормативно-правова основа політичних явищ та процесів) (Patrushev, 2001, s. 147), у неоінституціоналізмі (розглядаємо в узагальненому вигляді) акценти зміщуються від формальних структур до аналізу інституціональних полів, сукупності норм та цінностей або ж соціальних практик, звертається увага на соціокультурну обумовленість політичних процесів та інститутів, що дозволяє приймати до уваги неформальні практики як чинники становлення інститутів. Інститути в неоінституціоналізмі розглядаються під певним кутом зору - 3 точки зору «взаємозв'язку формальних норм та неформальних правил гри, що у результаті створюють складні організаційні відносини, форми взаємодії та саму кооперативну діяльність людей, що підтримують стабільність та відтворюють порядок у суспільстві» (Patrushev, 2001, s. 159).

Якщо для традиційного напрямку політичними інститутами постають у першу чергу державні установи та політичні організації, які розглядалися визначальними чинниками політичного процесу i від яких залежала діяльність політичних акторів та стабільність політичної системи, то неоінституціоналізм має більш широкий погляд на поняття «інституція» (в даній публікації поняття «інститут» та «інституція» $\epsilon$ синонімами), що 
відрізняється їх розглядом як «залежних», так i «незалежних змінних», які визначають політику та адміністративну поведінку (Piters, 1999, s. 219).

Дана властивість пов'язана із ідеєю конструктивізму, яку Н. Флігстін (2001, s. 29) визначає як спільну для усіх неоінституціоналізмів. Розкриваючи iii сутність, вчений наголошує на ролі акторів у створенні інститутів: створення та відтворення інститутів $є$ результатом взаємодії акторів, що відбувається на полях або аренах (локальні соціальні порядки), їх конструювання здійснюється через встановлені правила взаємодії та розподіл ресурсів; крім обмеження у діях акторів, інститути надають їм нові можливості (нестандартне використання правил для створення нових інститутів; використання інститутів для підтримки свого становища або пошуку нових арен) (Fligstin, 2001, s. 29).

Отже, можна зазначити - що даний напрям акцентує увагу на тому моменті, що інститути можуть як обмежувати поведінку індивідів через певний набір правил, так і зазнавати впливу зі сторони соціуму, «діючих» акторів. Так, Д. Норт (1997, s. 17), окреслюючи цю характеристику у своєму визначенні інститутів, наголошує, що це «правила гри» у суспільстві, ті «обмежувальні рамки», які встановлюються самими індивідами, в межах яких відбуваються ті чи інші взаємодії. Вказані «рамки» (правила, норми, санкції) виступають у ролі «інституційного середовища», а «інституційні практики» в даному випадку - це механізми (реалізуються через ті чи інші форми діяльності), що забезпечують дане «інституційне середовище (Patrushev, 2001, s. 152-153).

Тож, можна виокремити сутність політичних інститутів не тільки в традиційному руслі - як підтримку суспільно-політичної стабільності через контроль, регулювання соціально-політичних процесів та взаємовідносин між індивідами, інтеграцію індивідів до суспільно політичного життя, а й як «переведення настроїв людей у публічну політику» (Romaniuk, 2007, s. 34).

Через постійний взаємовплив, інститути не є сталими утвореннями (iх усталеність відносна), вони знаходяться у постійній динаміці, через що 
наголошується на відносній межі як між інститутами та процесами, так і між неформальними інститутами та культурою (Kolodii, 2011, s. 131).

Оскільки прихильники неоінституціоналізму намагаються пояснити, яким чином виникають і розвиваються політичні інститути, який вплив вони здійснюють на політичну поведінку індивідів та груп, на процес прийняття владних рішень, які чинники постають ключовими у зміні інститутів, політична поведінка індивідів аналізується в умовах і можливостях існування інститутів, можна визначити, що дану теорію вирізняє увага на значенні не просто інституцій як таких, а саме процесу інституціоналізації а також на особливостях розвитку формальних і неформальних інститутів, можливостях їх взаємозаміщення (Savelieva, 2019, s. 67).

У інтерпретації С. Хантінгтона (2004, s. 32) інституціоналізація визначається у якості процесу, за допомогою якого організації та процедури набувають цінності та стабільність. Необхідною умовою інституціоналізації, відтворення інститутів є легітимація. У зв’язку з цим в неоінституціоналізмі для розкриття сутності інститутів звертається увага на набір певних цінностей, у відповідності до яких члени організацій (за трактовкою Дж. Марча та Й. Олсена організації прирівнюються до інститутів) приймають рішення та вибудовують свою поведінку («логіка відповідності») (Piters, 1999, s. 221).

Як вже зазначалося, традиційні категорії політичної науки в межах неоінституціоналізму набувають нового сенсу, один 3 авторів «Історії політичної думки», Є. Перегуда (2017, s. 15) говорить навіть про еволюцію категоріально-понятійного апарату політології. Так, політика постає сферою, де на основі влади взаємодіють індивіди та групи з метою розподілу благ і ресурсів. Політична влада, в свою чергу, постає похідною людських взаємовідносин, а поняття політичного режиму визначається як автономна інституційна структура, що характеризує політичну систему країни, тобто виводиться на новий рівень, розглядається поза межами механізмів впливу державних установ на суспільство. Ще одне поняття, яке пропонують до 
використання вчені - «неоінституційна політика» (Perehuda, 2017, s. 17). Дане поняття можна пов’язати із терміном У. Бека (2000) «субполітика», яка приходить на зміну політики в суспільстві ризику - політика стає сферою не тільки уряду країн, а й сферою діяльності різноманітних груп чи окремих індивідів, що надає додатковий шанс для отримання влади і «діяльності влади» поза межами політичної системи. Є. Перегуда (2017, s. 17) вважає, що «така політика базується на активності соціальних рухів та організацій, сприяє новим» формам демократичної культури.

Висновки і перспективи подальших досліджень. Таким чином, виходячи 3 вищевикладеного, цілком можна припустити можливість використання у якості стратегії наукових розвідок в сучасних політичних дослідженнях неоінституціональний підхід.

Серед можливостей, які надає дана теорії в сучасних політичних розвідках, можна назвати наступні. По-перше - це використання міждисциплінарного підходу, що знаходиться в основі неоінституціоналізму (використання економічних, культурологічних та інших наукових знань, теорій), у розумінні як інституцій, так і системних та позасистемних політичних явищ та процесів. По-друге, ураховуючи сучасний перехід «реальної» політики у розряд «символічної» та популяризацію публічної політики, а також сучасні характеристики соціально-політичної реальності як нестабільної, плинної тощо, даний підхід допомагає розкрити не тільки формальні аспекти функціонування політичного процесу, а його реальні аспекти як через багаторівневий інституційний аналіз, так і з урахуванням неформальних компонентів політичного процесу. По-третє, в межах неоінституціоналізму розширюється спектр дослідження за рахунок залучення до аналізу не тільки «першочергових» політичних інститутів, але i «другорядних», в тому числі і неформальних. По-четверте, через призму неоінституціоналізму можна по-новому осягнути політичні явища та процеси (наприклад, через їх розгляд у якості практики, або ж з урахуванням 
трансакційних витрат, чи з урахуванням впливу інституційного середовища тощо).

Для раціонального використання можливостей нової інституційної теорії, слід окреслити можливі елементи в дослідницькій схемі неоінституціоналізму: в залежності від мети дослідження визначення рівнів аналізу, чи проведення дослідження комплексно, в межах усіх рівнів: інституційного, організаційного, індивідуального; розгляд об'єктів дослідження у якості інституціоналізованих практик, формальних/неформальних правил гри; аналіз інституційного середовища; аналіз соціокультурних контекстів; аналіз динаміки, результатів політики.

Слід зауважити, що, по-перше, визначення більш чіткої схеми дослідження потребує подальшого аналізу даної проблематики з апробацією на конкретних об’єктах, i, по-друге, не дивлячись на наявний евристичний потенціал теорії для сьогодення, iї певну самостійність та оригінальність, прислухаємось до авторитетної думки К. фон Байме, який зауважив, що неоінституціоналізм не може підміняти собою усе багатоманіття підходів, які існують у сучасній політичній науці (Kruglashova (Velch), 2014).

\section{ЛІТЕРАТУРА}

1. Аптер, Д. И., 1999. Сравнительная политология вчера и сегодня. В: Р. Гудин, Х-Д. Клингеманн, ред. Перевод с английского М. Гурвица, А. Демчук, Т. Якушева Политическая наука: новые направления. Москва: Вече. с. 361-386.

2. Байме, К., 2008. Політичні теорії сучасності. Переклад 3 німецької М. Култаєвої та М. Бойченка. Київ: Стилос.

3. Бек, У., 2000. Общество риска. На пути к другому модерну. Москва: ПрогрессТрадиция.

4. Ваславский, Я. И. и Габуев $\quad$ С. В., 2016. Неоинституциональный подход как методологическая основа исследования электронного правительства. Вестник МГИМО университета, 6(51), с. 60-75.

5. Денисенко, І. Д. та Тяпкіна, Ю. О., 2019.

\section{REFERENCES}

1. Apter, D. I., 1999. Sravnitelnaya politologiya vchera i segodnya. V: R. Gudin, H-D. Klingemann, red. Perevod s anglijskogo $\mathrm{M}$. Gurvica, A. Demchuk, T. Yakusheva Politicheskaya nauka: novye napravleniya. Moskva: Veche. s. 361-386.

2. Baime, K., 2008. Politychni teorii suchasnosti. Pereklad $\mathrm{z}$ nimetskoi $\mathrm{M}$. Kultaievoi ta M. Boichenka. Kyiv: Stylos.

3. Bek, U., 2000. Obshestvo riska. Na puti $k$ drugomu modernu. Moskva: ProgressTradiciya.

4. Vaslavskij, Ya. I. i Gabuev S. V., 2016. Neoinstitucionalnyj podhod kak metodologicheskaya osnova issledovaniya elektronnogo pravitelstva. Vestnik MGIMO universiteta, 6(51), s. 60-75.

5. Denysenko, I. D. ta Tiapkina, Yu. O., 2019. 
Армія сучасної держави: визначення стратегіï дослідження. Сучасне суспільство: політичні науки, сочіологічні науки, культурологічні науки, 1 (17), с. 7383.

6. Зазнаев, О.И., 2005. Вторая молодость «долгожителя»: концепт «политический институт» в современной науке. В: Проблемь политической науки. Казань: Центр инновационных технологий. с. 3-29

7. Кирилюк, Ф. М. 2009. Новітня політологія: навчальний посібник для студ. вищих навчальних закладів. Київ: Центр учбової літератури.

8. Кокарев, К. П., 2009. Концептуализация легитимности в новом институционализме. Политическая наука, 3, с. 39-55.

9. Колодій, А., 2011. Неоінституціоналізм та його пізнавальні можливості в політичних дослідженнях. Вісник Львівського університету. Філософсько-політологічні cmydiï, 1, c. 129-139.

10. Круглашова (Вельч), В. Д., 2014. Теоретические подходы к исследованию института международного наблюдения за выборами. Политология и право, [online] 4. Доступно: http://st-

hum.ru/content/kruglashova-velch-vdteoreticheskie-podhody-k-issledovaniyuinstituta-mezhdunarodnogo [Дата обращения 25 Ноябрь 2019].

11. Мэр, П., 1999. Сравнительная политология: общие проблемы В: Р. Гудин, XД. Клингеманн, ред. Перевод с английского M. Гурвица, А. Демчук, Т. Якушева Политическая наука: новые направления. Москва: Вече. с. 309-330.

12. Норт, Д., 1997. Институть, институцииональные изменения $u$ функиионирование экономики. Перевод с английского А. Н. Нестеренко. Москва: Фонд экономической книги «Начала».

13. Патрушев, С. В., 2001. Институционализм в политической науке: этапы, течения, идеи, проблемы. Политическая наука, 2, с. 146186.

14. Патрушев, С. В., 2009. Институциональная политология: четверть века спустя. Политическая наука, 3, с. 5-19.

15. Перегуда, Є. В., 2017. Політичні ідеї
Armiia suchasnoi derzhavy: vyznachennia stratehii doslidzhennia. Suchasne suspilstvo: politychni nauky, sotsiolohichni nauky, kulturolohichni nauky, 1 (17), s. 73-83.

6. Zaznaev, O. I., 2005. Vtoraya molodost «dolgozhitelya»: koncept «politicheskij institut» v sovremennoj nauke. V: Problemy politicheskoj nauki. Kazan: Centr innovacionnyh tehnologij. s. 3-29

7. Kyryliuk, F. M. 2009. Novitnia politolohiia: navchalnyi posibnyk dlia stud. vyshchykh navchalnykh zakladiv. Kyiv: Tsentr uchbovoi literatury.

8. Kokarev, K. P., 2009. Konceptualizaciya legitimnosti $\mathrm{V}$ novom institucionalizme. Politicheskaya nauka, 3, s. 39-55.

9. Kolodii, A., 2011. Neoinstytutsionalizm ta yoho piznavalni mozhlyvosti v politychnykh doslidzhenniakh. Visnyk Lvivskoho universytetu. Filosofsko-politolohichni studii, 1, s. 129-139.

10. Kruglashova (Velch), V. D., 2014. Teoreticheskie podhody $\mathrm{k}$ issledovaniyu instituta mezhdunarodnogo nablyudeniya za vyborami. Politologiya i pravo, [online] 4. Dostupno: http://sthum.ru/content/kruglashova-velch-vdteoreticheskie-podhody-k-issledovaniyuinstituta-mezhdunarodnogo

[Data obrasheniya 25 Noyabr 2019].

11. Mer, P., 1999. Sravnitelnaya politologiya: obshie problemy V: R. Gudin, H-D. Klingemann, red. Perevod s anglijskogo $\mathrm{M}$. Gurvica, A. Demchuk, T. Yakusheva Politicheskaya nauka: novye napravleniya. Moskva: Veche. s. 309-330.

12. Nort, D., 1997. Instituty, institucionalnye izmeneniya $i$ funkcionirovanie ekonomiki. Perevod s anglijskogo A.N. Nesterenko. Moskva: Fond ekonomicheskoj knigi «Nachala».

13. Patrushev, S. V., 2001. Institucionalizm V politicheskoj nauke: etapy, techeniya, idei, problemy. Politicheskaya nauka, 2, s. 146186.

14. Patrushev, S. V., 2009. Institucionalnaya politologiya: chetvert veka spustya. Politicheskaya nauka, 3, s. 5-19.

15. Perehuda, Ye. V., 2017. Politychni idei 
представників неоінституціоналізму. $\mathrm{B}$ : Н. М. Хома, ред. Історія політичної думки: підручник: у 2-х m. T.2.: XX-початок XXI cm. 2-е вид., перероб. і доп. Львів: «Новий Світ-2000».

16. Питерс, Б. Г., 1999. Политические институты: вчера и сегодня В: Р. Гудин, ХД. Клингеманн, ред. Перевод с английского M. Гурвица, А. Демчук, Т. Якушева Политическая наука: новые направления. Москва: Вече. с. 218-235.

17. Романюк, А. С. 2007. Порівняльний аналіз політичних інститутів країн Західної Європи: монографія. Львів: Вид. центр ЛНУ імені Івана Франка.

18. Савельєва, Т. П., 2019. Суспільно-політичні рухи як чинник державотворення: політико-інституиійний вимір. Кандидат наук. Харківський національний педагогічний університет імені Г.С. Сковороди

19. Флигстин, Н., 2001. Поля, власть и социальные навыки: критический анализ новых институциональных течений. Экономическая соииология, 2(4), с. 28-55.

20. Хантингтон, С., 2004. Политический порядок в меняюшихся обществах. Москва: Прогресс-Традиция.

21. Beyme, K., 2005. Wspolczesne teorie polityczne. Wydawnictwo Naukowe SCHOLAR. Warszawa.

22. Rhodes, R.A.W. and Burder, S.A. eds., 2006. The Oxford Handbook of Political Institutions. Oxford. predstavnykiv neoinstytutsionalizmu. V: N. M. Khoma, red. Istoriia politychnoi dumky: pidruchnyk: u 2-kh t. T.2.: XX - pochatok $X X I$ st. 2-e vyd., pererob. i dop. Lviv: «Novyi Svit-2000».

16. Piters, B. G., 1999. Politicheskie instituty: vchera i segodnya V: R. Gudin, H-D. Klingemann, red. Perevod s anglijskogo M. Gurvica, A. Demchuk, T. Yakusheva Politicheskaya nauka: novye napravleniya. Moskva: Veche. s. 218-235.

17. Romaniuk, A. S. 2007. Porivnialnyi analiz politychnykh instytutiv krain Zakhidnoi Yevropy: monohrafiia. Lviv: Vyd. tsentr LNU imeni Ivana Franka.

18. Savelieva, T. P., 2019. Suspilno-politychni rukhy yak chynnyk derzhavotvorennia: polityko-instytutsiinyi vymir. Kandydat nauk. Kharkivskyi natsionalnyi pedahohichnyi universytet imeni H.S. Skovorody

19. Fligstin, N., 2001. Polya, vlast i socialnye navyki: kriticheskij analiz novyh institucionalnyh techenij. Ekonomicheskaya sociologiya, 2(4), s. 28-55.

20. Hantington, S., 2004. Politicheskij poryadok $v$ menyayushihsya obshestvah. Moskva: Progress-Tradiciya.

21. Beyme, K., 2005. Wspolczesne teorie polityczne. Wydawnictwo Naukowe SCHOLAR. Warszawa.

22. Rhodes, R.A.W. and Burder, S.A. eds., 2006. The Oxford Handbook of Political Institutions. Oxford.

\section{Інформація про авторів}

Бабухіна Світлана Анатоліївна - старший викладач кафедри політології, соціології і культурології Харківського національного педагогічного університету імені Г.С. Сковороди; e-mail babuhina@gmail.com. ORCID: http://orcid.org/0000-0001-66328496.

Савельєва Тетяна Павлівна - викладач кафедри політології, соціології i культурології Харківського національного педагогічного університету імені Г.С. Сковороди; e-mail: savelyeva.tp@gmail.com; ORCID: http://orcid.org/0000-00033274-6475.

Стаття надійшла до редакції: 18.11.2019 р. Прийнята до друку: 05.12.2019 р. 